Milesa Srećković ${ }^{1}$, Suzana Polić ${ }^{2}$, Milivoje Ivković3, Zoran Karastojković ${ }^{4 *}$, Milica Vinić ${ }^{3}$, Aleksander Kovačević3 Slobodan Bojanić ${ }^{5}$

${ }^{1}$ Faculty of Electrical Engineering, University of Belgrade, Serbia ${ }^{2}$ Central Institute of Conservation, Belgrade, Serbia, ${ }^{3}$ Institute of Physics, University of Belgrade, Serbia, ${ }^{4}$ HIS Techno Experts, Belgrade, Serbia, ${ }^{5}$ Universidad Politechnica, Madrid, Spain
Scientific paper

ISSN 0351-9465, E-ISSN 2466-2585

UDC: $681.7 .069 .24-049.8: 069.01$

doi: $10.5937 /$ zasmat2004275S

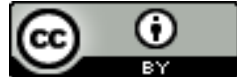

Zastita Materijala 61 (4)

$275-285(2020)$

\title{
Contemporary laser techniques, general application in heritology and case of building in 7 Balkanska street, Belgrade
}

\begin{abstract}
It seems that the role of lasers in heritology and art has grown more and more since the end of the $20^{\text {th }}$ century; the early attempts of cleaning artistic objects, old monuments / artifacts during the times of Hedy Lamarr and the first unsuccessful nuclear tests as well as of thinking of holographic records. After the first series of circumstances linked to laser applications in restoration and conservation, it seems the coupling of words serendipity-zemblanity-bahramdipity has been activated. A long time has passed since the first works linked to the Porta della carte of the Palazzo Ducale (Doge's Palace) in Venice (marble relief and ruby laser). Nowadays, this type of work can be treated as standardized and it is implemented in great number of countries [1, 2]. In the case of Florence Cathedral, the conservation of artworks was proposed by J. F. Fonatello, panels of the Giotto's tower of the Florence Cathedral by Andrea Pisano.

The unique roles of quantum generators - lasers - exist both in restoration and diagnostics. Besides that, the question of source existence - a source that provides completely new artistic impression with respect to its ideal characteristic of coherency - introduced new tools and techniques and could be (and was) implemented in many new processes and effects. New artistic directions were performed, where the source of the coherence became a part of a new artistic object, a hologram slide provokes the impression of the train entering the crowd, etc. [1-5] The laser role by using LIBS method in diagnostics in the case of the building in 7 Balkanska street, Belgrade, was presented in this paper.
\end{abstract}

Keywords: laser methods, LIBS, heritology, spectroscopy.

\section{INTRODUCTION}

\subsection{Laser methods}

Considering of large meaning of cultural heritage, generalization of material study could be monitored through: mechanical, corrosion, optical, dielectric, acoustic or other performances and appropriate methods. Special role in monitoring is paid to lasers scattering either in static or dynamic regimes. Some of methods cover quantum generators in the region of ultrafast regimes (zeptos) up to CW regimes. They are of interest for diagnosis of material quantifications including the shape of treated artifacts of cultural heritage. The most usual are quasi elastics Rayleigh, Brillouin, Raman scattering and their variants.

\footnotetext{
${ }^{*}$ Corresponding author: Zoran Karastojković

E-mail: zoran.karastojkovic@gmail.com

Paper received: 24. 03.2020.

Paper corrected: 10. 06. 2020.

Paper accepted: 08. 09. 2020.

Paper is available on the website: www.idk.org.rs/journal
}

Laser spectroscopies with complementary techniques (infrared - IR), could be applied as a tool for the investigation of microstructure up to residual stresses. With inclusion of holographic methods many answers could be obtained (seismic data of environment). Note that first mentioned laser scattering is employed also for control of ejected particles (material) by laser cleaning of artifacts [1-9]. Material performances are expressed in various formalisms that include complex expression of all response functions and higher orders of magnitudes in the case of nonlinear optics. Depending on input laser parameters and demanded responses, respective techniques should be chosen. Contemporary theories and optical/acoustic methods give new possibilities and links with mechanical elastic moduli. Values for sound speed in materials implemented in calculations of characteristic frequency shifts could be used in corresponding laser techniques (stimulated Brillouin scattering). It is obtained by monitoring basic laser lines, scattered line shapes, their shifts and provoked other nonlinear effects, when the intensity of incident laser beam exceeds threshold values for 
stimulated processes (second harmonic generation - SHG - up to the disintegration level-threshold for hardness of material to radiation). Note that the obtaining the prediction of the disintegration threshold from measured linear Rayleigh components $[10,11]$ is important.

The answer on fundamental relationships which link the interactions of electron, $X$, gamma and other photon (quasi-photon) beams of electromagnetic (EM) radiation with relations between moment and energy, is sought during making the decision which technique will be used for measuring the chosen processes [6]. The key parameter in selection of measuring techniques is energy transfer vs. moment transfer during scattering of various beams of radiation and particles.

Details could be followed through abundance of literature on ELION techniques, ELION being oneword abbreviation which denotes electrons, lasers, ions and neutrons [6,12]. Interesting conclusion could be retrieved on the choice of measuring techniques/spectroscopy (visible photons, X-rays, neutrons) comparing flux of monoenergetic quanta, associated wavelength, $\Delta \lambda / \lambda$, coherent volume, degeneration parameter and quantum counting efficiency. Being new sources with frequency tuning, numerous laser types open possibilities for obtaining various relaxation times and monitoring of solid state dynamics. Abundance of literature provides some characteristics of sources of optical photons, neutrons and X-rays, which are used for purposes of scattering or of material interaction. During examining the interaction of EM radiation with material, is necessary to use classical tools for considering light scattering as like Maxwell theory, Hertz's potentials and Poynting vector.

Many techniques, including micro-interferometry, can be used for the estimation of practical technological questions in the research of metals, surface roughness/relief and the effects caused by various processing regimes. Of particular importance is to study the effects of processing finesse to surface reflectance. Surface physics and the propagation of ELION beams through two or more different milieux are particularly intricate areas both from experimental and from theoretical approaches [12].

\subsection{Categories of newer spectroscopies}

Spectroscopies have intruded in various areas of life: science and engineering and new categories with nano-particles have their place [12-18]. They master the same techniques which had been developed for sophisticated purposes of military or civil applications, and swiftly transfer to everyday use. In such way, they helped each other in the frame of physics-chemistry-technology of materials, and measurement techniques. Instruments for reflection measurements in non-linear range are complex, and the moments of phase transitions could be monitored, rate of crystallization with laser-assisted processes, plasma phenomena, etc. In measurement hierarchy, precise measurements of reflection coefficient of various materials, leads to lower and higher-quality definition of material's reflective characteristics (color, gloss, haze, etc.). Results of radiation-matter interaction (melting, evaporation and ejection processes, microhardness changes etc.) are not in accordance with data obtained by the spectroscopic analyzes of ejected material [19].

Surface physics could be treated as a branch of science for the processes on the phase borders [14-16]. Basic surface parameters (composition, atomic distribution, electron states, morphology and texture), have a direct influence on functional characteristics: optical, mechanical, chemical, electrical and magnetic. This is important for material synthesis in contemporary technologies: nanoelectronics, optoelectronics, heterogeneous catalysis, protective layers with high microhardness and with long chemical durability, magnetic memories. For most of them, a task for quantum generators and stimulated processes could be defined. Many developed experimental techniques differ by the object of measurement: sensitivity, information depth, lateral resolution and destruction. There is no technique which encloses only positive aspects, not even for a unique object of measurement. Complementary techniques have become the rule. Many of them are connected to laser-material interactions. Among them are: direct recoiled spectroscopy (DRS) and low-energy ion scattering spectroscopy (LEIS), used for compound analysis and the distribution of atoms. The list of techniques is broadened with mass analysis, secondary ion mass spectroscopy (SIMS) and mass spectroscopy of direct recoiled ions (MSRI). They provide deep profiles to analysis. LEIS and DRS are superior to SIMS and MSRI in surface sensitivity. The implementation of laser spectroscopies can give: electron structure, surface symmetry, surface morphology by laser speckle analysis, dynamic processes on surfaces. They are non-destructive and are used for analysis of both transparent and non-transparent materials. Obtained information on optical characteristics enables research of phase boundaries inside sample. Detailed examinations in situ of epioptics implemented to good characterization of system under ultrahigh vacuum (UHV) still are not numerous. 
At least 17 new methods for characterization of dielectric susceptibilities of various orders in formalisms of nonlinear and epioptics could be found as a support. The same holds for optical absorption measurements where are calorimetry, photothermal, photoacoustical, photoconductive and photoluminiscence excitation spectroscopies. Some of new techniques as LIBS (Laser Induced Breakdown Spectroscopy), LAMS (Laser and Molecular Spectroscopy), LAMMA (Laser Microprobe Mass Analysis), SHG (Second Harmonic Generation), and other non-linear techniques are linked to microscopic destructive processes. Some of our results are linked to computer approaches that may lead to transformations for melting or other phase changes. With respect to materials (dielectric, metal and semiconductor) and dynamical regimes of operation, new theories could be included for ultrashort interaction (some of them already penetrated into nucleus). Specially, fields that include up-to-now separated processes are developed thank to non-linear phenomena.

\section{THE CASE STUDY OF BUILDING IN 7 BALKANSKA STREET AND LIBS SPECTROSCOPY}

In case of the building of the Central Institute for Conservation (CIK) in Belgrade, various methods should be applied for obtaining an objective comparison between old and contemporary conditions, always in accordance with the regulations of heritage preservation and construction requirements. Diagnostics could be performed by laser and conventional techniques and in this paper weather stripping (mortar) is analyzed by LIBS. More informations could be obtained after the implementation of several techniques, which can be used for the estimation of the age and quality of old or recent materials, used since the construction times to contemporary times.

Besides conventional methods, new methods for historical houses with walls of pressed soil and weather stripping - mortar - have also been analyzed and developed nowadays [20-22]. Characterization usually begins from old methods, but among the new ones many are based on quantum generators in various working regimes. (Old methods for better understanding weather stripping/mortar include many of next characterizations: proportioning - water, consistency, water/cement ratio, water/binder ratio, compressive strength, flexural strength, elasticity modulus, density of hardened mortar, capillary water absorption; diagnosis of main parameters affecting contact area between mortar/weather stripping rendering and substrate - 3D laser scanning). There are many publications about historical engineering materials of the object implemented. A number of test groups have been set. These are the characterizations of chemical and mineralogical characteristics, physical and mechanical characteristics, particle distributions and trembling. The determinations can be grouped into two instrumental techniques: XRF/XD and SEM/XRD, as well as the adaptations of standard UNE-EN methods for investigations and qualifications of these materials. The example of the ramps in Seville and Malaga may serve as a case study. It is a masonic construction of modular type, where weather stripping has been put and it has been filled with dirt and other components and tamping down in batches.

Rammed earth is in the focus of research of old buildings: in the context of sustainable building, contemporary interest for the earth as an engineering material is widely developed. Heritage of rammed earth in Europe and world is significant and scientific approach is being held. Durability and sensitivity to water, thermal characteristics, life comfort and mechanical compressive strength should have been taken into account.

\subsection{Short Historical background of building}

Here, some historical details of analyzed object will be presented. The object was erected for business purposes, built in around 1925. It is shaped in the spirit of late academism with elements of secession in decorative solution in the gable from the central part of the roof, and fences of the balconies of floor etages. Façades are flat and simply shaped with shallow side riyalites with encapsulated windows. The name of the architect who conducted the project is unknown, because the original documentation disappeared during the bombing of Belgrade in the $2^{\text {nd }}$ World War. From the aspect of protection agency, it is valorized as an architectural-urban value harmoniously incorporated into the historical ambient of the Terazije area which enjoys the status of the heritage under previous protection.

It is in the same lot with Anker Palace, which was built by "Anker" Vienna Insurance Company in 1899 under the project of architect Milan Antonović. This area incorporates "Atina" palace, hotel "Moskva", the house of Aleksa Krsmanović and the building of the Bank of Smederevo as a part of a representative civil engineering ensamble of Terazije formed in the end of the $19^{\text {th }}$ and the beginning of $20^{\text {th }}$ century [23].

In Figs. 1 and 2. the pictures of the object are presented, including details of deteriorated surfaces.

Layers of mortar (weather stripping) are clearly visible on many places. 




Figure 1. Front view of the main front façade of the object

Slika 1. Pogled sa prednje strane na glavnu fasadu objekta

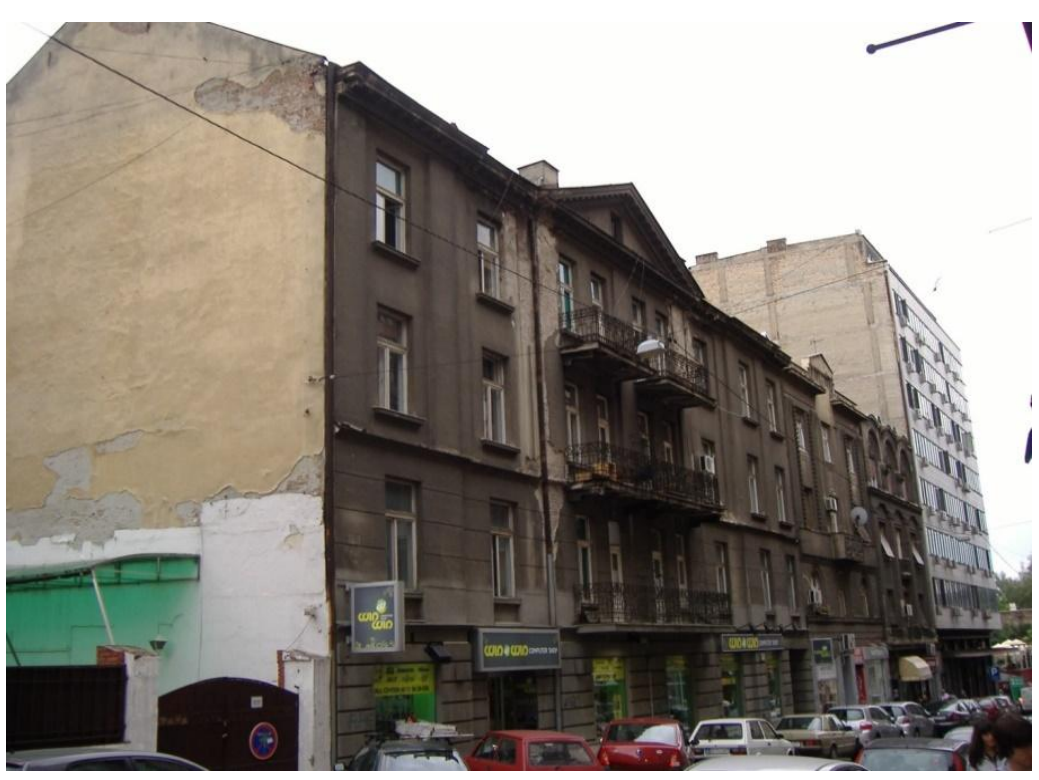

Figure 2. Another view of the main façade of the object

Slika 2. Bočni pogled na glavnu fasadu objekta

\subsection{Some performed experiments with LIBS for further restoration}

Part of the study of buildings of interest for cultural heritage could be and should include the state of the building's material. There are many standard techniques for the testing of the civil engineering materials [21, 22, 24-27]. Having in mind that here it started with laser techniques suitable for buildings, their parts, interiors and exteriors, first usable techniques could be and are LIDAR, scanner, range finders, and other developed systems that are based on some of the quantum generators [28-30]. Here is chosen the state of weather stripping from some special places that are selected from by experts from the field of restoration [23]. In theory, material for restoration should be, if possible, similar to the initial used material.

LIBS (or LIPS) is chosen parallel with other non-laser systems and methods to reveal and specify components of selected samples of mortar (weather stripping) from the façades. For the beginning, here is started with LIBS experiments. It means that there is a possibility to analyze the interaction between laser beam and mortar (weather stripping) or to see the contents of the material. Further analysis with complementary 
techniques is expected to reveal whether the material is from the time when building has been erected or some other details about influence of weather stripping on mortar up to day. LIBS techniques could be defined through $\sim 18$ techniques among which are based on the interaction of various laser types: micro-destructive 2 , destructive 10, non-destructive 6 (among which some of them are both destructive and nondestructive). LIBS system is micro-destructive was non-portable in the beginning [22]. LAMMA is excluded in the table from this reference. LIBS is chosen as a relatively new technique for material analysis; it is linked to the development of lasers, spectrometers and detectors.

LIBS techniques show lower precision compared to other analytical methods, but in turn are contactless and suitable as a preliminary investigation. The methods are characteristic for their complexity of interaction, but some depend on chosen laser and material. In general, the methods are based on the analysis of plasma radiation. The emission spectrum of provoked plasma consists of atomic, ionic and molecular states, etc. The inhomogeneity and time dependent changes of the shape of LIBS plasma are followed by the change of plasma parameters, specific distribution, spectral lines and the emission in plasma plume. Therefore, the spectra interpretation might be hindered [2838].

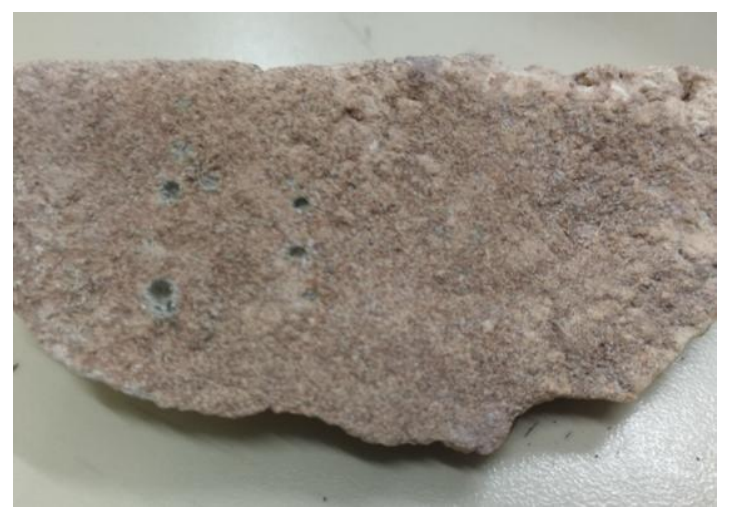

Figure 3. Mortar sample ( $\approx 5 \mathrm{~cm}$ long) subjected to analysis with microdamages provoked by LIBS

Slika 3. Uzorak maltera ( $\approx 5 \mathrm{~cm}$ dužine) za analizu; mikrooštećenja su nastala tokom LIBS analize

One of the samples, presented in Fig. 3, has subjected to the analysis of weather stripping composition by monitoring the most intensive recorded lines. Those samples will be the object for further investigations, respecting to the interaction with one or more laser beams. Here, the damage obtained by LIBS is presented as macroscopic view and further by spectral diagrams, with markings on curves offered by LIBS. After those recordings, the same samples will undergo to XRD analysis, and provoked microdamages need applying using techniques as SEM or TEM, may be other complementary spectroscopies.

\subsection{LIBS spectra of mortar samples}

Here, three samples were selected for the analysis with notation as follows:

1. Sample 1 - small grey mortar;

2. Sample 2 - large grey mortar;

3. Sample 3 - pink mortar.

The plasma was generated by a $\mathrm{Nd}^{3+}: Y A G$ laser (Q-smart 450) emitting 5 ns pulses at 1064 $\mathrm{nm}$. The beam was guided by mirror $\left(45^{\circ}\right.$ angle) to focusing lens of $10 \mathrm{~cm}$ focal length placed perpendicularly to the target. The mortar target was positioned $1 \mathrm{~mm}$ in front of the focal point, so the $0.5 \mathrm{~mm}$ spot was obtained. The incident laser energy on the sample was $500 \mathrm{~mJ}$. In such conditions, the laser fluence was $2.5 \mathrm{~J} / \mathrm{mm}^{2}$.

In Fig 4, the macrosopic image of a crater after LIBS action is presented as a detail from Fig. 3. The damages could be the object of further analyses in the aim of finding the relation between laser parameter and provoked damages at the materials. Here, in the first plane, are only the results of the analysis of ejected materials via plasma phenomena.

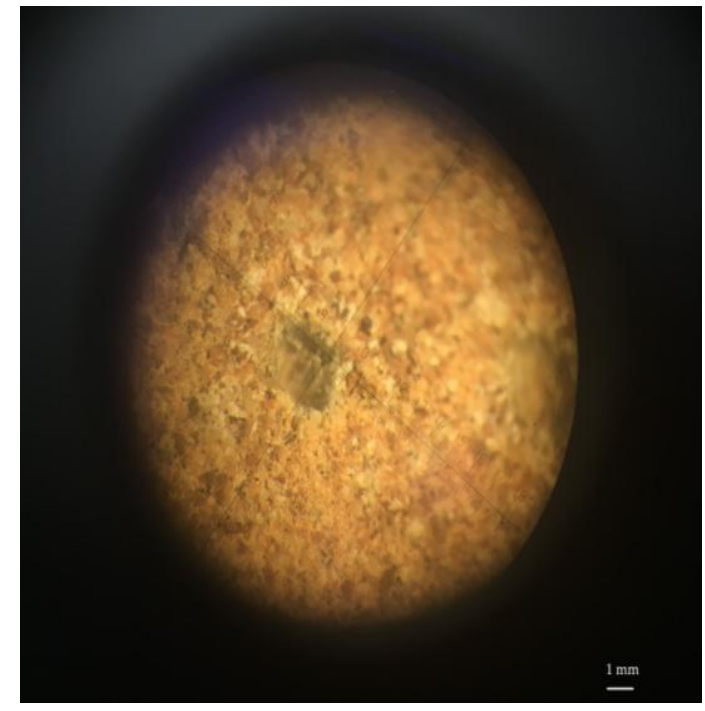

Figure 4. Macrograph of the area marked as $B$ 9955, recorded by optical camera

Slika 4. Makrosnimak površine označene
kao B 9955, snimljeno optičkom kamerom

Generally, there is not much difference in the shape and qualitative parameters of the created damages. Plasma radiation was through the entrance slit $(50 \mu \mathrm{m}$ wide) of the Shamrock 303 (Andor) imaging spectrometer using mirror and quartz achromatic lens (focal length $f=33 \mathrm{~cm}$ ). The change of the diffraction grating $(300,1200$ or 2400 
grooves $/ \mathrm{mm}$ ), slit width and wavelength position were performed using commercial Andor Solis software. The instrumental width with 1200 grooves $/ \mathrm{mm}$ grating and $50 \mu \mathrm{m}$ slit width, determined using Oriel penlight calibration lamps was $0.35 \mathrm{~nm}$.

The acquisition gate width, $t_{G}$, and delay, $t_{D}$, are determined with digital delay generator, DDG (Stanford Research Systems SRS, Model DG535). The spectra were recorded using gate delay of 0.6 $\mu \mathrm{s}$ and gate width of $100 \mu \mathrm{s}$. Such gating is a standard LIBS procedure which prevents the recording of pronounced continuum radiation in the first $0.6 \mu \mathrm{s}$. Much faster decay of the background emission versus line emission opened the possibility for improvement of $\mathrm{S} / \mathrm{N}$ ratio of lines of interest by selecting proper time for spectra recordings. The accumulation of the signal was necessary due to the very weak signal of lines. For that reason every spectra were accumulated over 10 laser shots.

In Figs. 5-10, some characteristic LIBS spectra of samples are presented by using common denotation which are commonly used in describing of LIBS results, according to the appropriate literature [32-34].

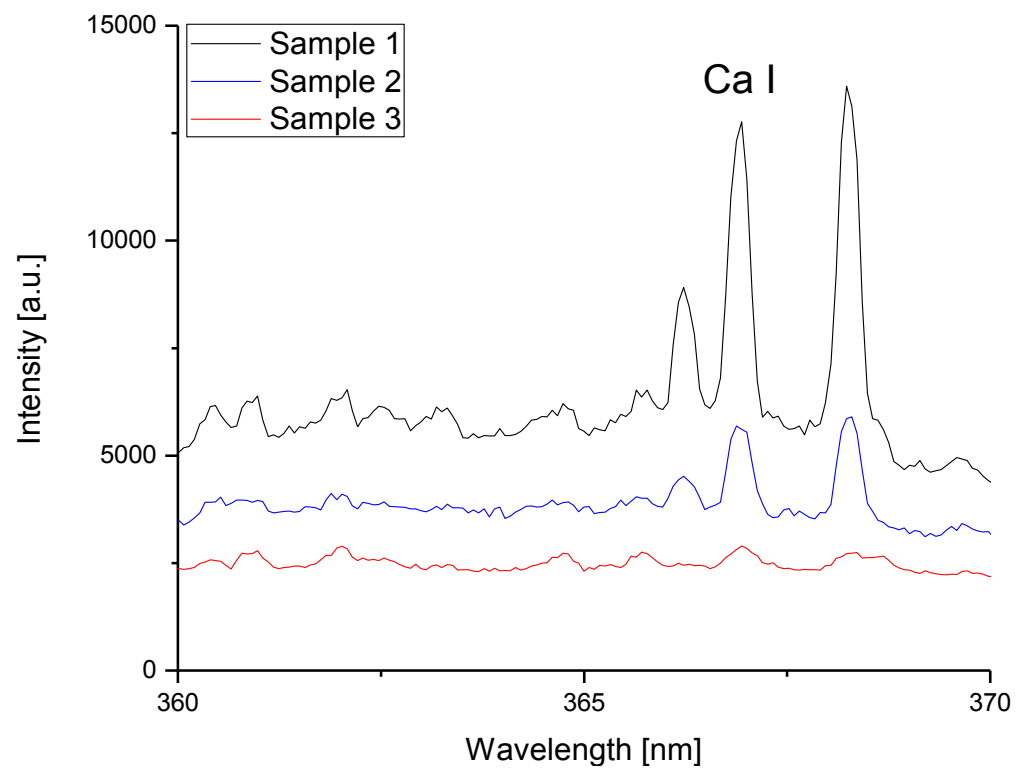

Figure 5. LIBS of the samples in the range $360-370 \mathrm{~nm}$

Slika 5. LIBS uzoraka u opsegu frekvencija $360-370 \mathrm{~nm}$

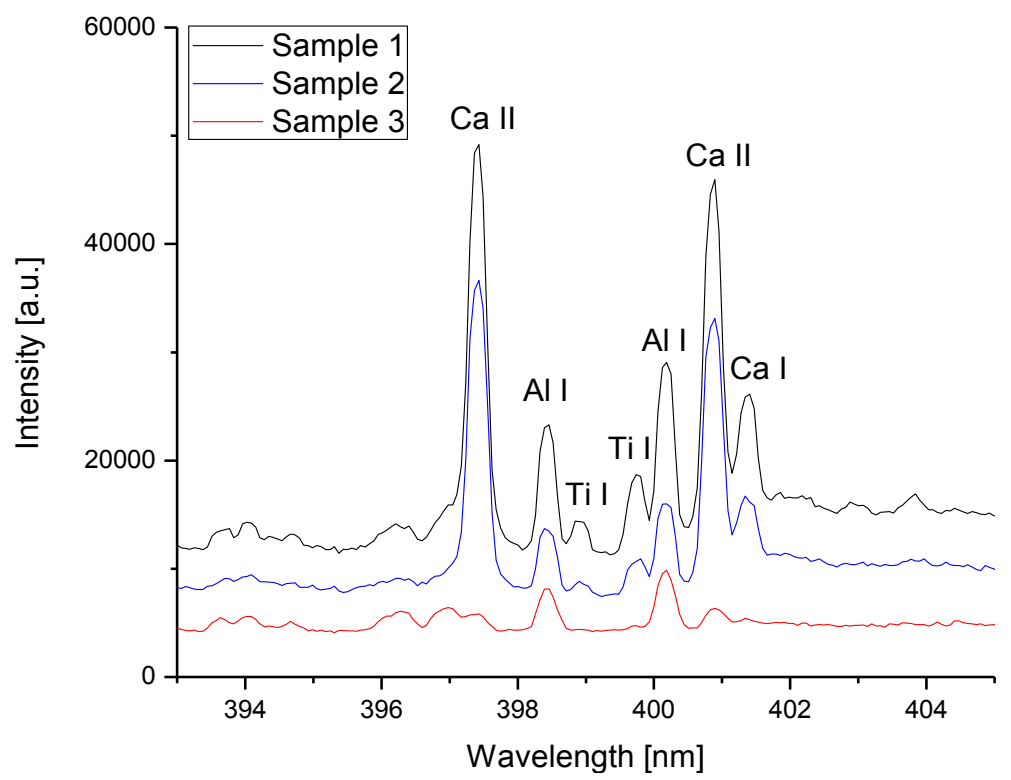

Figure 6. LIBS of the samples in the range $394-404 \mathrm{~nm}$

Slika 6. LIBS uzoraka u opsegu frekvencija 394-404 nm 


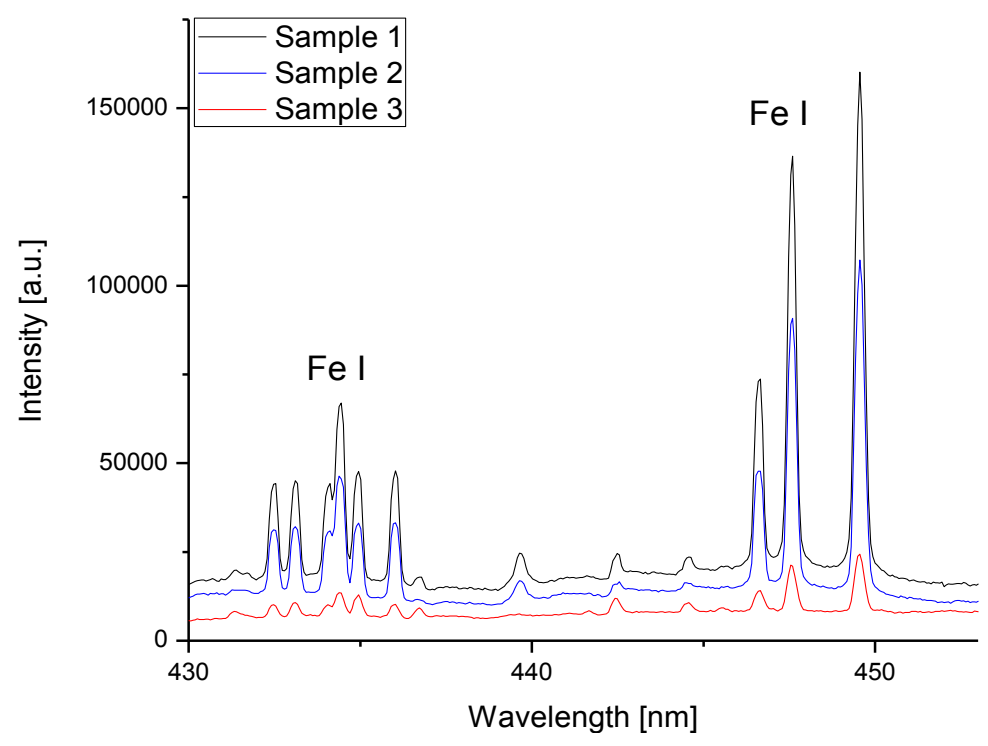

Figure 7. LIBS of the samples in the range $430-450 \mathrm{~nm}$

Slika 7. LIBS uzoraka u opsegu frekvencija $430-450 \mathrm{~nm}$

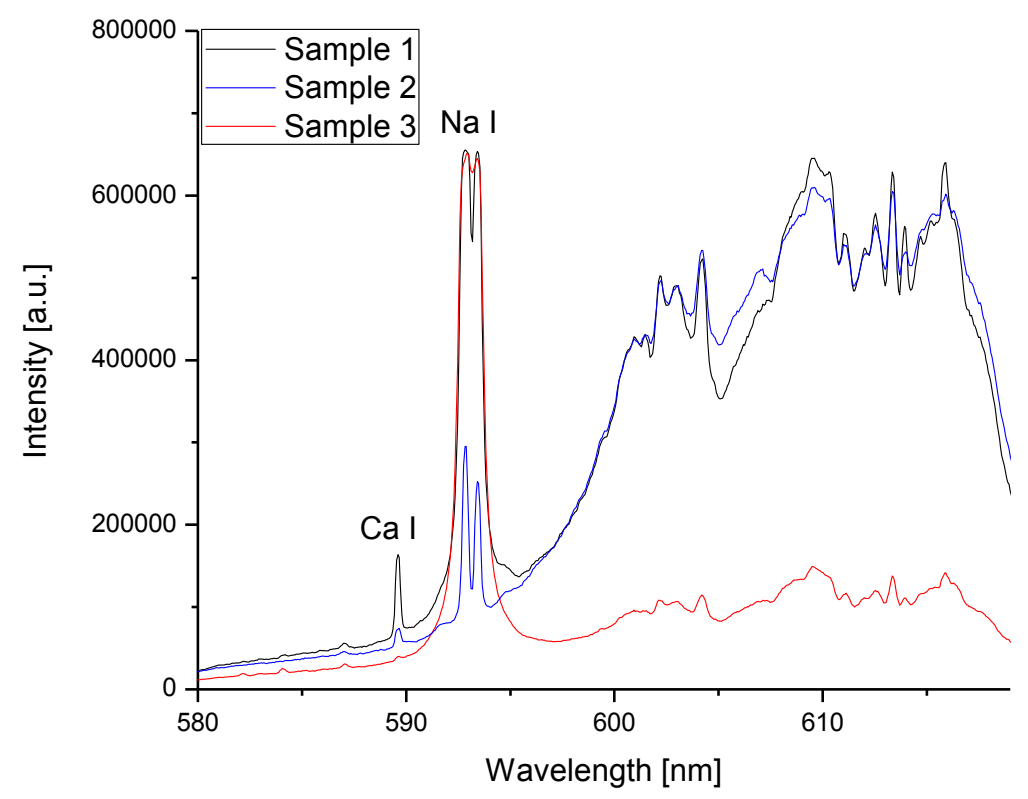

Figure 8. LIBS of the samples in the range $580-618 \mathrm{~nm}$

Slika 8. LIBS uzoraka u opsegu frekvencija 580-618 nm

\section{DISCUSSION}

For this preliminary investigation of chosen samples, LIBS was used as contactless method which provokes minor material damage. Detailed investigation of material and the interpretation of obtained LIBS data, however, are in correlations in complex theoretical and experimental facts, as a consequence of searching the correlations between the found element position at the Periodic table, their characteristic constants linked to ionisation, thermodynamics data, surface physics also with depth of the laser provoked craters, etc.

LIBS spectra from Figs. 5-10 represent the identification of several elements found in samples 1-3. At those wavelengths and recording parameters, here are registered peaks from resonant transitions of those elements (in form of excited ions), when excitation is performed during 
interaction of laser beam with target surface, assuming that multi-photon transitions did not take place. The aim in this moment is to find out preliminary results, and after that to use various other methods based on other systems as nondestructive spectroscopies but more conservative methods, in which the sample will be crushed to powder state. Other techniques might be used for defining specimen's color, before and after laser treatments in solid state, by using quantitative formalisms, etc.



Figure 9. LIBS of the samples in the range $640-660 \mathrm{~nm}$

Slika 9. LIBS uzoraka u rasponu frekvencija 640-660 nm

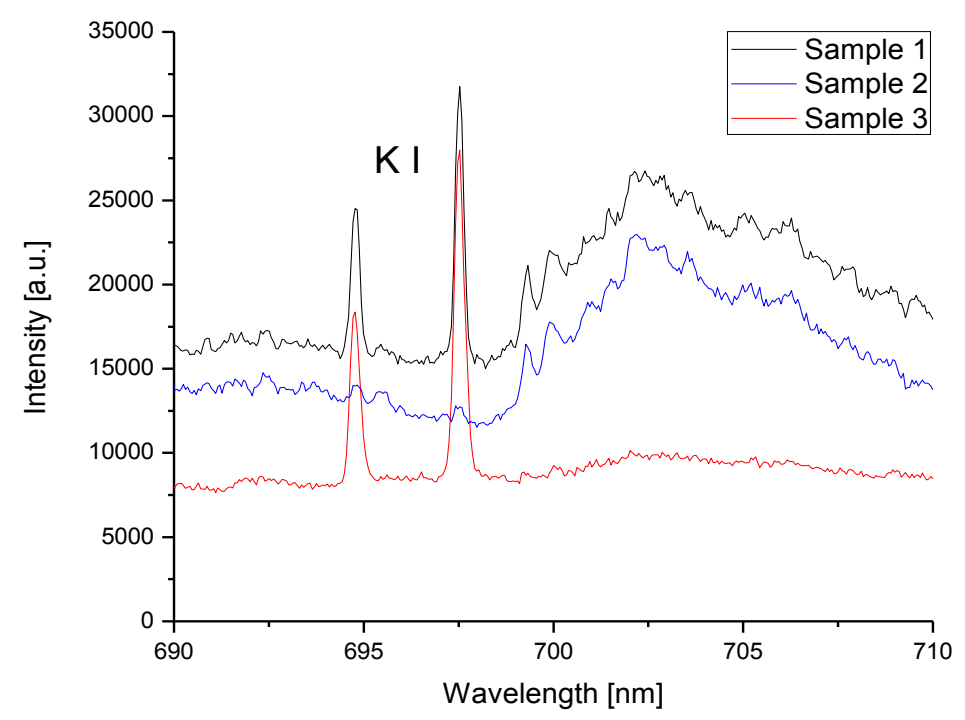

Figure 10. LIBS of the samples in the range $690-710 \mathrm{~nm}$

Slika 10. LIBS uzoraka u rasponu frekvencija 690-710 nm

The explanation of provoked dynamic plasma state is complex task that presume to use complementary techniques and theoretical models. Our approach was to perform experiments and to analyze the most intensive detected processes. By analyzing the spectroscopic view in short range of wavelengths, only the most intensive peaks were found and identified as clear representatives of existing transitions. Each laser spectroscopy as well as spectroscopy with non-coherent sources is 
characterized with their own spectroscopy formalisms. Note that in some of them parallel exist two formalisms. Here are used common notations for LIBS, and its database in which are recognized the state of some constituent of samples. The identification of $\mathrm{Al}$ or $\mathrm{Ti}$ could be found in the literature $[37,38]$. More details for composition of used samples should be expected in further investigation, for example by using infrared (IR), Raman and other techniques as well as XRD, or chemical analysis. For Raman and IR spectra there is a direct correspondence among the two spectra which enables the interpretation of the connection between the materials, their bonds etc.

For materials with unknown content, as is in the case of cultural heritage artefacts, it is necessary to damage the specimen as little as possible. Sample preparation for electron microscopy or some other technique needs the transformations of sample into powder. In this way, the samples will be completely destroyed and lost for further evaluations.

Spectra of two grey mortar samples are similar, with all analyzed lines in small grey mortar sample spectra being more intensive. In grey mortar sample spectra it was possible to detect $\mathrm{Ti}$ I which is not present in pink mortar sample. Nevertheless, those given lines are detected also in pink mortar sample, in which their intensities are significantly greater, together with the concentration of given elements: Fe I, Ca I, Al I. The only difference between two grey mortar samples is that the small grey mortar sample has $\mathrm{K} \mathrm{I}$, while large grey mortar sample has not. In the pink mortar sample spectrum $\mathrm{K}$ dominates. There is more $\mathrm{Na}$ than in grey mortar samples. In the spectrum, the lines of $\mathrm{Fe} \mathrm{I,} \mathrm{Ca} \mathrm{I,} \mathrm{Al} \mathrm{I} \mathrm{are} \mathrm{also} \mathrm{detected,} \mathrm{but} \mathrm{they} \mathrm{are} \mathrm{of}$ significantly lower intensity than in grey mortar samples. These initial data could be used for further refinement of the LIBS measurement possibility.

\section{CONCLUSION}

Chosen examples from the cultural heritage here are investigated by LIBS, which was developed on the basis of long-term research and couplings with laser-plasma-diagnostics-production methods. Comparing the damages of three samples, it could be noticed that there are no much differences in the shape and quantitative parameters of the performed damages.

Since laser induced breakdowns cause complex atmospheric compositions, identification is performed among ion transition of the elements as like $\mathrm{Ca}, \mathrm{Na}, \mathrm{Al}, \mathrm{Fe}$, $\mathrm{Ti}$, when characteristic notations were used as valuable for this spectroscopic method. At wavelengths applied here it was not possible to register elements as like silicon or oxygen, for which other laser or non-laser techniques should be used in further investigations, due to the complexity of the problem.

For further investigation, the answers according to the question on the relation between SEM and EDX to the LIBS method, their advantages also disadvantages of these parallel techniques, are expected. Discussions on various contemporary and classical types of mortar and other applications of laser related with cleaning of façades will be provided.

\section{Acknowledgement}

The paper is realized under the support from the Ministry of Culture and Information of the Republic of Serbia, as well as the support from the Ministry of Education, Science and Technological Development of the Republic of Serbia, No. TR340128, No. III45016.

\section{REFERENCES}

[1] a) J.F.Asmus, Serendipity, Punctuated, pp.1-9; ASMUS ch. 6, Springer Proceedings in Physics 116 ; b) Laser cleaning of cultural heritage, Assorestauro,

https://www.assorestauro.org/en/projects/cubaiila2015/from-qa-022015/laser-cleaning-ofcu8ltural-heritage.html.

[2] a) North façade of Florence Cathedral restored, The Florentine, www.theflorence.net/2019/03/ 30/north-facade-florence-cathedral-restored/, accessed 2019-12-30; b) Cathedral of Florence, a portion of the restoration completed, RossoRubino, www. rossorubino.tc/en/cathedrale-di-firenze-terminata-una-porzione-del-restauro/, accessed 2019$12-30$; c) Lasers in the Conservation of Artworks, Lacona VI Proc., Vienna, Sept. 21-25, 2005.

[3] M.Srećković, A.Bugarinović, V.Svoboda, N. Kovačević, M.Janićijević, N.Borna, N.Kovačević, M. Janićijević, Z.Fidanovski (2013) Selected Aspects of Laser applications in the preservation of cultural heritage, Contemporary Materials, 103, 539-563.

[4] M.Srećković, S.Ostojić, S.Polić, A.Kovačević, S. Jevtić, N.Borna, N.Ratković-Kovačević, Z. Fidanovski, A.Milosavljević (2016) Laser techniques in ecology, cultural heritage preservation and other contemporary tasks, in Serbian, Energija, ekonomija, ekologija, 18(3-4), 23-34.

[5] M.Srećković, S.Polić, A.Bugarinović, V.Svoboda (2016) Laser and problems of conservation of cultural heritage, in Serbian, Center for talents "Belgrade 2", Belgrade.

[6] S-H.Chen, S.Yip (2018) Spectroscopy in Biology and Chemistry: Neutron, X-Ray, Laser [PrintReplica] KindleEdition.

[7] M.Srećković, M.Kutin, S.Ristić, S.Milić, B. Kaluđerović, M.Janićijević (2006) Nonconventional techniques for evaluation of residual stress with accent on IR and microraman spectroscopy in material investigation, Technical Diagnostics, 2(5), 20-29. 
[8] M.Srećković, A.Bugarinović, Ž.Tomić, A. Kovačević, V.Rajković (2012) Laser interaction with material in theory, experiment and reality, Regionalni centar za talente Belgrade II.

[9] Y.R.Shen (2003) The principles of nonlinear optics, Wiley Interscience, New York.

[10] M.Srećković, S.Ostojić, B.Đokić, V.Zarubica, A Kovačević, M.Nešić (2010) Scattering, reflection transmission in theory and practice, the estimation of nonlinear and ultrafast phenomena, Atti dela fondazione Giorgio Ronchi, 64(4,5), 543-555.

[11] M.Srećković, S.Blanchard, A.N.Titschenko, J. P.Leicknam (1986) Rapports de Rayleigh, isotropes and anisotropes, facteurs de diffusion moléculaire anisotrope $\left(F_{a n}\right)$ et anisotropies optique moléculaires du phytol et de quelques solvants organiques mésurés à $632,8 \mathrm{~nm}$ avec un laser HeNe, Portugal Physics, 17(3-4), 181-202.

[12] M.Srećković, M.Kutin, M.Hribšek, M.Pavlović, S. Polić-Radovanović, V. Zarubica (2009) Applications of ELION and other techniques in measurement, control and processing of materials, Institute "Goša", Society for technical diagnostics of Serbia, Belgrade.

[13] M.Srećković, J.llić, M.Davidović, B.Đokić, Ž.Tomić, Z.Latinović, D.Družijanić (2009) Laser interaction with material - theory, experiments and discrepancies, Acta Physica Polonica A, 116(4), 618-621.

[14] J.C.Vickerman (1997) Surface Analysis-The Principal Techniques, J. Wiley \& Sons, Chichester.

[15] Z.Ristić (2007) Mass and laser spectroscopy for surface analysis, Master Thesis, Faculty of Electrical Engineering, Belgrade.

[16] The Science and Culture Series - Physics, Series Editor: A. Zichichi (2018) Proceedings of the $43^{\text {th }}$ Course of the International School of Solid State Physics, EPIOPTICS-10, Ed. A. Cricenti.

[17] M.Srećković, V.Zarubica, M.Dinulović, S.Milić, A. Janićijević, A.Bugarinović (2009) Laser techniques based on laser maerial interaction and transformation, Contemporary Materials 2008, p.169-191, Banja Luka, 4-5 juli.

[18] W.Amendola (2016) Laser generated nanoparticles and nanoalloys with plasmonic and magnetic properties for lasers and nanomedicine applications, p-73-78, in Nano for Health, Eds. P. R. Andjus, P. M. Spasojević, P. Battinelli, Associazione Italiane e Serbi, Scienciati e studenti Belgrado, Belgrade.

[19] B.V.Kaludjerović, M.Srećković, M.Janićijević, A. Kovačević, S.Bojanić (2017) Influence of $\mathrm{Nd}^{3+}$ : YAG laser irradiation on the properties of composites with carbon fibers, Composites, part B. Engineering, 125, 165-174.

[20] D.Lj.Jevtić (2017) Selected chapters/topics from contemporary materials in civil engineering, University of Belgrade - Faculty of Civil Engineering, Belgrade.

[21] Recent Developments in Building Diagnosis Techniques (2016) ed. by J. M. P. Q. Delgado, Springer, Singapore.
[22] Ch.Zhao, Yi.Zhang, Chong-Chen Wang, Mi.Hou, Al.Li (2019) Recent progress in instrumental techniques for architectural heritage materials, Heritage Science, 36(50), 7-13.

[23] „Conditions for establishing measures of technical protection for reconstruction and sanation of facades of the objects in 26 Terazije street," KP2981, KO Stari grad (Old town municipality) in Belgrade, project for the Institute for the protection of cultural monuments of the city of Belgrade, No. 43/19 May $16^{\text {th }}, 2019$ (author of the principal project of the revitalization of the façade is Tatjana Vudenović, dipl arch. from the Institute of protection of the cultural monuments of the city of Belgrade).

[24] M.Srećković, S.Ostojić (2018) Paradigmes, definitions and border conditions of laser techniques of interest for cultural heritage, Conference on trend of heritology in industrial and intangible cultural heritage Belgrade, Belgrade.

[25] A.T.Delegou, G.Mourghi. E.Tsilimantou, Ch. loannides, A.Moropolou (2019) A Multidisciplinary Approach for Historic Buildings Diagnosis: The Case Study of the Kaisariani Monastery, Heritage, 2, 1211-1232, www.mdpi.com/journal/heritage.

[26] APLAR 6 Laser cleaning technology for the conservation and restoration, http://www. iiconservation.org/node/6960, Retrieved December 27, 2019.

[27] Restoration of Frescoes, in Higher Education in Restoration and Cultural Heritage, Palazzo Spinelli Group, www.palazzospinelli.org/eng/course.asp?id=firenze \&idn=176. Retrieved December 27, 2019.

[28] P.Vujković Cvijin, D.Ignjatijević, I.Mendaš, M. Srećković, L.Pantani, I.Pippi (1987) Reflection Spectra of Terrestrial Surface, Material at $\mathrm{CO}_{2}$ Laser Wavelength: Effects on DIAL and Geological Remote Sensing, Appl. Opt., 26, 4323-4330.

[29] M.Srećković. I.Pippi, S.Ostojić, N.Rakočević (2002) Contemporary LIDAR Application, Technics LVII, No. 3 / Electrotechnics, 51,1-12, in Serbian.

[30] M.Srećković, M.Pavlović, Z.Vejnović, S.Ostojić (2015) Lidari, ladari, colidari, diali, Studio 789 TEAM, Belgrade, in Serbian.

[31] D.A.Cremers, L.J.Radziemski (2009) History and Fundamentals of LIBS, in Laser Induced Breakdown Spectroscopy, ed. by A. W. Miziolek, V. Palleschi, I. Schechter, Cambridge University Press, Cambridge, p.1-39.

[32] M.Vinic, M.Ivkovic (2014) Laser ablation initiated fast discharge for spectro-chemical applications, Chemical Industry, 68, 381-388.

[33] M.Vinic, M.Ivkovic (2014) Spatial and Temporal Characteristics of Laser Ablation Combined with Fast Pulse Discharge, IEEE Transaction on Plasma Science, 42(10), 2598-2599.

[34] M.B.Cvejić (2014) Space and time spectroscopic diagnostics of laser induced plasma on solid target in air on atmospheric pressure, PhD dissertation, Faculty of Electrical Engineering University of Belgrade, Belgrade. 
[35] A.Kovacevic, I.Stefanovic (1996) Backpropagation Neural Network Algorithm for Deconvolution of Voigt profiles, XVIII SPIG Conference, Kotor (September 2-6, 1996), Contributed papers, p.334.

[36] V.Shapoval, E.Marotta, C.Ceretta, N.Konjević, M. Ivković, M.Schiorlin, C.Paradisi (2014) Development and Testing of a Self-Triggered Spark Reactor for Plasma Driven Dry Reforming of Methane, Plasma Process. Polym., 11, 787-797.
[37] T.Walid (2007) Fast LIBS identifications of Aluminium Alloys, Progress in Physics, 2, 87-92.

[38] J.Ciganović (2020) Pulsed laser action on titanium target: surface effects, PhD Thesis, Faculty of Electrical Engineering, University of Belgrade, Belgrade, in Serbian.

\section{IZVOD}

\section{SAVREMENE LASERSKE TEHNIKE I OPŠTA PRIMENA U HERITOLOGIJI I SLUČAJ ZGRADE U BALKANSKOJ ULICI 7, BEOGRAD}

Čini se da je uloga lasera $u$ heritologiji i umetnosti u stalnom porastu od kraja 20. veka; rani su pokušaji čišćenja umetničkih objekata, starih spomenika ili artefakata od vremena Hedi Lamar (Hedy Lamarr) i prvih neuspešnih nuklearnih testova, kao i razmišljanja o holografskim zapisima. Posle prve serije okolnosti vezanih za primene laserskih tehnika u restauraciji i konzervaciji, izgleda da je sprezanje reči serendipity, zemblanity $i$ bahramdipity aktivirano. Prošlo je mnogo vremena otkad su obavljeni prvi radovi vezani za Porta della Carta Duždeve palate (Palazzo Ducale) u Veneciji - mermerni reljef i rubinski laser. Danas ovaj tip radova može da se tretira kao konvencionalan/standardan i primeni u nizu zemalja [1, 2]. U slučaju Katedrale u Firenci Fonatelo (J. F. Fonatello) je predložio konzervaciju umetničkih objekata, Pizanove (Andrea Pisano) panele na Đotovoj (Giotto) kuli Katedrale.

Jedinstvene uloge kvantnih generatora - lasera - postoje i u restauraciji i u dijagnostici. Osim toga, pitanje postojanja izvora - izvora koji nudi potpuno novi umetnički utisak u odnosu na idealne osobine koherencije - uvelo je nove alate i tehnike i moglo je da (i jeste) primeni mnogo novih procesa i efekata. Novi umetnički pravci su izvedeni, gde je izvor koherencije postao deo novog umetničkog objekta, hologram je izazvao utisak da voz ulazi u masu ljudi, itd. [1-5] Uloga lasera u dijagnostici $i$ u svrhu konzervacije $i$ neke primene na slučaj zgrade u Balkanskoj 7 u Beogradu je prikazana $u$ ovom radu.

Ključne reči: laserske metode. LIBS, heritologija, spectroskopija.

Naučni rad

Rad primljen: 24. 03. 2020.

Rad korigovan: 10. 06. 2020.

Rad prihvaćen: 08. 09. 2020.

Rad je dostupan na sajtu: www.idk.org.rs/casopis

(C) 2020 Authors. Published by Engineering Society for Corrosion. This article is an open access article distributed under the terms and conditions of the Creative Commons Attribution 4.0 International license (https://creativecommons.org/licenses/by/4.0/) 